\title{
Valutazione di alcuni parametri di epatotossicità di nevirapina ed efavirenz su oltre 700 pazienti trattati per infezione da HIV. Assenza di connessioni con il sesso femminile ed una conta di linfociti CD4+ elevata
}

\author{
Roberto Manfredi, Leonardo Calza \\ Dipartimento di Medicina Clinica Specialistica e Sperimentale, Sezione di Malattie Infettive, "Alma Mater Studiorum" \\ Università di Bologna, Policlinico S. Orsola-Malpighi, Bologna
}

Key words: Hepatotoxicity, nevirapine, efavirenz, gender, CD4+ T-lymphocyte count, baseline laboratory values, naïve patients, pre-treated subjects, salvage antiretroviral therapy

Parole chiave: Epatotossicità, nevirapina, efavirenz, sesso, conta dei T-linfociti CD4+, assetto laboratoristico iniziale, pazienti naïve, soggetti pre-trattati, terapia antiretrovirale di salvataggio

Assessment of some parameters of liver toxicity of nevirapine and efavirenz on over 700 patients treated for HIV infection. No relationship with the female sex, and an elevated CD4+ lymphocyte count

\section{SUMMARY}

Despite some recent reports which claimed the hypothesis of an increased hepatotoxicity of the antiretroviral drug nevirapine in female patients with a CD4+ lymphocyte count above 250 cells/ $\mu \mathrm{L}$ (especially pregnant women), in our open-label comparison of 742 patients treated for the first time with either a nevirapine or an efavirenz-based HAART as completely naïve patients, experienced subjects, and patients on salvage antiretroviral therapy, we did not disclose any increased hepatotoxicity in nevirapine-treated subjects, in particular with regard to both gender (females versus males), and HIV-related immune deficiency (as represented by a CD4+ count above versus below 250 cells $/ \mu \mathrm{L})$.

\section{RIASSUNTO}

Nonostante alcuni recenti segnalazioni abbiano avanzato l'ipotesi di un'aumentata tossicità epatica del farmaco antiretrovirale nevirapina nei soggetti di sesso femminile con livelli di linfociti CD4+ superiori a 250 cellule/ $\mu \mathrm{L}$ (specialmente in corso di gravidanza), in uno studio aperto di confronto comprendente 742 pazienti trattati per la prima volta con una terapia antiretrovirale di combinazione (HAART) comprendente nevirapina o efavirenz, suddivisi come soggetti del tutto naïve ad antiretrovirali, pazienti pre-trattati, e soggetti in terapia antiretrovirale di salvataggio, non abbiamo rilevato un incremento degli indici di epatotossicità nel gruppo di pazienti che ricevevano nevirapina, ed in particolare abbiamo escluso un'aumentata tossicità epatica a seconda del sesso (donne versus uomini) e dell'entità del deficit immunitario HIV-correlato (rappresentato da una conta di T-linfociti CD4+ superiore a 250 cellule/ $\mu \mathrm{L}$, versus una conta inferiore a 250 cellule/ $\mu \mathrm{L})$.

\section{INTRODUCTION}

A broad spectrum of mechanisms may sustain the hepatotoxicity prompted by highly active antiretroviral therapy (HAART). Non-nucleoside reverse transcriptase inhibitors (NNRTI) form a very easy class to be explored, since it presently includes only two major compounds (nevirapine and efavirenz), which share extensive genotypic cross-reaction, so that in the great majority of cases a prior failure with one component precludes the use of the second derivative (3).

Although several studies did not underline a remarkable difference in major efficacy parameters compared with efavirenz $(1,13,17,19)$, how- ever since 2002 efavirenz retains its recommendation in antiretroviral-naïve patients due to its superior intrinsic anti-HIV activity $(1,3,13)$, while nevirapine is very often suggested as a part of switch, simplification, or de-intensification regimens in patients who achieved a sustained viral suppression and a complete immune reconstitution (3), but suffered from a broad spectrum of adverse events, or an excessive pill burden (3, $9,10,13,15)$, as well as a component of rescue treatments (13).

All these issues, together with a convenient administration and a favorable pharmacoeconomic profile (as represented by $57.12 \%$ lower cost 
compared with efavirenz, with even more difference versus protease inhibitors) (16), are valid reasons of the continued, extensive use of nevirapine in 2006 daily clinical practice, just when a retrieved immune recovery is almost the rule, and the female gender is more and more represented among treated HIV-infected patients $(13,15)$. Unfortunately, since early 2005 some reports conducted on small patient series underlined an increased liver toxicity just in pregnant women with a CD4+ count $>250$ cells $/ \mu \mathrm{L}(6,7)$, and were accompanied by a specific FDA advisory issued on January 2005 (14), which pointed out and apparently enlarged and modified "... warnings against ongoing nevirapine treatment in women with a CD4+ count over 250 , due to a greatly increased risk of serious liver toxicity.

The warnings do not apply to single-dose nevirapine, which does not cause this problem" (14). This last FDA statement does not seem well substantiated, since the large majority of studies were conducted on pregnant women (5-7) (while the advisory included all women, regardless of pregnancy) (14), and it was stated that single-dose nevirapine was less toxic than b.i.d. administration, while the large $2 \mathrm{NN}$ study demonstrated a slight increased toxicity just for once-daily nevirapine administration (19), other non-comparative surveys failed in retrieving reduced hepatotoxicity with once-daily nevirapine (1), a very recent Cochrane review (17) underlined a possible increased toxicity when nevirapine is delivered once daily (17), and also pharmacokinetic studies disclosed greater $\mathrm{C}_{\min } / \mathrm{C}_{\max }$ nevirapine values when this drug is administered once daily (8).

Later, a large retrospective study published in the year 2006 and regarding 197 pregnant women exposed to nevirapine for at least 7 days, disclosed a $5.6 \%$ overall rate of toxicity, no fatalities, and especially no serious hepatotoxicity save one case of grade- 4 cholestasis (possibly attributable to underlying conditions) (6).

In the meantime, some authors detected unpredictable serum nevirapine concentrations, which could be responsible for adverse events (and liver toxicity in particular), in selected patients $(2,8)$.

\section{PATIENTS AND METHODS}

In our single-centre open-label experience conducted among $>1,000$ patients treated with HAART for at least 12 months, the hepatotoxicity pattern of both available NNRTI was assessed on the ground of three different backgrounds (as previously described) $(9,12)$ : patients naïve to all antiretrovirals, starting a NNRTI-based HAART regimen; subjects experienced with 2-10 subsequent therapeutic lines (but still NNRTI-naïve); and finally patients who added a NNRTI only on late rescue therapies containing four or more different anti-HIV drugs (and always including at least one protease inhibitor). Only patients with nevirapine delivered $200 \mathrm{mg}$ twice daily were considered.

Of 846 overall patients matching these characteristics, 64 subjects were excluded from analysis due to an adherence level lower than $90 \%$ (as assessed by spontaneous patients' declarations, and direct drug distribution and accountability performed at our inpatient centre), 31 due to subsequent efavirenz and/or nevirapine use, and 9 more patients were not considered since they took all the nevirapine dosage $(400 \mathrm{mg})$ once daily.

Patients on pregnancy were not admitted to the present study, since efavirenz use is an exclusion criterion for pregnant women. Student $t$ test (or Fischer exact test) and chi-square test (or MantelHaenzel chi-square test) were used when appropriate, with significance levels placed at $p<.05$.

\section{RESULTS}

Of 742 evaluable subjects, 346 consecutive patients treated with nevirapine were compared with 396 consecutive patients who took efavirenz, by a 12-36-month univariate and multivariate analysis of serum liver abnormalities, on the ground of a large spectrum of epidemiological, clinical, and laboratory parameters (table 1).

Instead of normal laboratory levels, we referred to the respective baseline value of each enrolled patient.

The two study groups were comparable as to the main demographic and epidemiological features, and clinical stage of HIV disease, while a lower CD4+ lymphocyte count was found in patients who started efavirenz $(p<.00001)$, as well as greater HIV viremia $(p<.001)$; actually, this last difference regarded only the 93 antiretroviralnaïve patients (data not shown). Moreover, in an univariate analysis no differences were found as to type and duration of eventual prior anti-HIV therapy, frequency and length of treatment with protease inhibitors or anti-tubercular therapy, eventual HCV-HBV-HDV co-infection, or other chronic hepato-biliary and pancreatic disorders (biliary gallstones, cholecistitis, pancreatitis), and alcohol-drug abuse, or substitutive methadone administration.

An at least two-fold increase of serum transaminases compared with baseline values was significantly linked with nevirapine versus efavirenz use $(p<.00001)$. The time to peak serum transaminase alterations was shorter in the nevirapine versus the efavirenz group $(p<.00001)$, and hepatotoxicity represented the main determinant of therapy 
interruption in 20 patients who received nevirapine, versus five cases belonging to the efavirenz group $(p<.001)$ (table 1).

More frequent alterations were also detected for serum bilirubin $(p=-05)$, gamma-GT $(p<.0004)$, alkaline phosphatase $(p=.003)$, and albumin levels $(p=.05)$ in the nevirapine versus the efavirenz patient group (data not shown).

All differences were carefully controlled per each available variable: a link between frequency and time to peak serum transaminases and NNRTI therapy withdraval due to hepatotoxicity, was disclosed for concurrent HBV-HCV-HDV infection plus chronic hepato-biliary-pancreatic disorders only at logistic regression multivariate analysis $(p<.03)$ (data not shown).

Particularly, when stratifying all enrolled patients per gender and an initial CD4+ lymphocyte count $>250$ cells $/ \mu \mathrm{L}$, no statistically significant difference emerged among patients taking either nevirapine or efavirenz, even after careful control for all other variables (table 1).

Finally, no differences were found when analyzing the three patient groups at enrollment, i.e. the 93 antiretroviral-naïve patients, the 503 subjects treated with 2-10 different therapeutic lines, and the 146 patients on salvage therapies containing $\geq 4$ drugs, but who remained naïve to NNRTI (data not shown).

Table I. A comparison of selected variables of the 346 patients treated with nevirapine, compared with those of the 396 subjects who took efavirenz.

\begin{tabular}{|c|c|c|c|}
\hline Patients' features & $\begin{array}{l}\text { Nevirapine group } \\
(\mathrm{N}=346)\end{array}$ & $\begin{array}{l}\text { Efavirenz group } \\
(\mathrm{N}=396)\end{array}$ & $\begin{array}{l}p \\
\text { value }\end{array}$ \\
\hline Age (mean \pm SD) & $34.4 \pm 12.8$ & $33.9 \pm 13.6$ & n.s. \\
\hline Gender (males / females) & $245 / 101$ & $294 / 102$ & n.s. \\
\hline HIV exposure (heterosexuals /MSM / i.v.DA) & $116 / 89 / 141$ & $132 / 101 / 163$ & n.s. \\
\hline Mean length of overall follow-up (months $\pm S D$; range) & $18.4 \pm 8.7 ; 12-36$ & $19.1 \pm 8.5 ; 12-36$ & n.s. \\
\hline $\begin{array}{l}\text { HIV disease stage } \\
\text { (N. patients with AIDS or } \mathrm{CD} 4+<200 / \mu \mathrm{L})\end{array}$ & 27 & 33 & n.s. \\
\hline $\begin{array}{l}\text { Antiretroviral therapy (all patients were naïve to NNRTI) } \\
\text { - patients naïve to all antiretrovirals } \\
\text { - patients treated with } 2-10 \text { prior antiretroviral lines } \\
\text { - patients on rescue therapy ( } \geq 4 \text { drugs, including } \mathrm{PI} \text { ) } \\
\text { Length of prior antiretroviral therapy (months } \pm \text { SD) } \\
\text { Length of prior PI administration (where applicable) } \\
\text { (months } \pm S D \text { ) }\end{array}$ & $\begin{array}{l}41 \\
244 \\
61 \\
96.9 \pm 38.6 \\
87.2 \pm 38.7\end{array}$ & $\begin{array}{l}52 \\
259 \\
85 \\
99.2 \pm 40.8 \\
82.6 \pm 48.7\end{array}$ & $\begin{array}{l}\text { n.s. } \\
\text { n.s. } \\
\text { n.s. } \\
\text { n.s. } \\
\text { n.s. }\end{array}$ \\
\hline Baseline CD4+ lymphocyte count (mean \pm SD) & $303.4 \pm 98.2$ & $367.6 \pm 101.6$ & $p<.00001$ \\
\hline Baseline mean viremia ( $\log _{10} \mathrm{HIV}$-RNA copies $/ \mathrm{mL}$ ) & $4.1 \pm 1.12$ & $4.5 \pm 0.95$ & $p<.00001$ \\
\hline $\begin{array}{l}\text { Patients with drug / alcohol abuse; } \\
\text { or methadone administration }\end{array}$ & $16 / 10 / 21$ & $21 / 11 / 24$ & n.s. \\
\hline $\begin{array}{l}\text { Patients who underwent anti-tubercular therapy } \\
\text { - length of antitubercular therapy (months } \pm S D \text { ) }\end{array}$ & $\begin{array}{l}23 \\
9.3 \pm 4.2\end{array}$ & $\begin{array}{l}21 \\
8.8 \pm 4.8\end{array}$ & $\begin{array}{l}\text { n.s. } \\
\text { n.s. }\end{array}$ \\
\hline Eventual HCV / HBV / HDV co-infection & $46 / 9 / 1$ & $57 / 13 / 3$ & n.s. \\
\hline $\begin{array}{l}\text { Patients with other chronic hepato- } \\
\text { biliary-pancreatic disorders }\end{array}$ & 23 & 27 & n.s. \\
\hline Serum baseline ALT / AST levels (mean U/L $\pm S D$ ) & $46.2 \pm 10.6 / 51.3 \pm 10.2$ & $245.4 \pm 12.6 / 52.6 \pm 9.9$ & n.s. \\
\hline - patients developing $\geq 2$-fold increase of ALT/AST levels & 92 & 54 & $p<.00001$ \\
\hline - time to peak serum transaminases (months $\pm S D$ ) & $6.2 \pm 3.1$ & $9.7 \pm 5.6$ & $p<.00001$ \\
\hline $\begin{array}{l}\text { - patients who interrupted the selected NNRTI } \\
\text { - due to hepatotoxicity }\end{array}$ & 20 & 5 & $p<.001$ \\
\hline $\begin{array}{l}\text { Patients developing } \geq 2 \text {-fold increase of ALT/AST levels } \\
\text { - male / female patient ratio } \\
->250 \text { CD } 4+\text { cells / }<250 \text { CD } 4+\text { cells } / \mu L \text { ratio }\end{array}$ & $\begin{array}{l}71 / 21 \\
76 / 16\end{array}$ & $\begin{array}{l}39 / 15 \\
46 / 8\end{array}$ & $\begin{array}{l}\text { n.s. } \\
\text { n.s. }\end{array}$ \\
\hline $\begin{array}{l}\text { Time to peak serum transaminases (months } \pm \text { SD) } \\
- \text { male / female patient ratio } \\
->250 \text { CD } 4+\text { cells } /<250 \mathrm{CD} 4+\text { cells } / \mu \mathrm{L} \text { ratio }\end{array}$ & $\begin{array}{l}5.9 \pm 2.9 / 6.0 \pm 3.3 \\
9.5 \pm 5.8 / 9.9 \pm 5.4\end{array}$ & $\begin{array}{l}6.1 \pm 3.2 / 6.3 \pm 3.4 \\
9.6 \pm 5.7 / 9.8 \pm 5.5\end{array}$ & $\begin{array}{l}\text { n.s. } \\
\text { n.s. }\end{array}$ \\
\hline $\begin{array}{l}\text { Patients who interrupted the selected NNRTI } \\
\text { due to hepatotoxicity } \\
- \text { male / female patient ratio } \\
->250 \mathrm{CD} 4+\text { cells / }<250 \mathrm{CD} 4+\text { cells } / \mu \mathrm{L} \text { ratio }\end{array}$ & $\begin{array}{l}14 / 6 \\
11 / 9\end{array}$ & $\begin{array}{l}3 / 2 \\
3 / 2\end{array}$ & $\begin{array}{l}\text { n.s. } \\
\text { n.s. }\end{array}$ \\
\hline
\end{tabular}

$\mathrm{SD}=$ standard deviation; $\mathrm{MSM}=$ men who had sex with men; i.v. DA= intravenous drug abusers; $\mathrm{NNRTI=}$ non-nucleoside reverse trascriptase inhibitors (nevirapine or efavirenz); $\mathrm{Pl}=$ protease inhibitors 


\section{DISCUSSION}

Obviously, nevirapine-containing HAART regimens remain more hepatotoxic than efavirenzbased ones $(4,9,10,12,18)$, and a key role may be played by underlying chronic viral hepatitis and hepato-biliary-pancreatic disorders, as previously demonstrated (11). As assessed in our study conducted on 742 evaluable patients who received a NNRTI for the first time in different baseline conditions, the female gender and a CD4+ lymphocyte count exceeding 250 cells $/ \mu \mathrm{L}$ do not prompt any adjunctive hepatotoxicity risk.

In the meantime, also very recent studies and extensive literature revisions underlined the longterm efficacy and safety profile of nevirapine $(1,4$, 15). In particular, a multicentre experience recruited 613 patients treated with nevirapine for at least two years (median follow-up 43 months): increases by 5 times of more in AST/ALT values were observed in less than $2 \%$ of cases, while overall viral suppression ranged around $75 \%$ of patients (including naïve patients, failing subjects, and those switching for prior toxicity) (1). Also Dieterich et al. (4), when reviewing the 1996-2000 US Food and Drug Administration (FDA) databases for liver toxicity of several antiretroviral compounds (including data from 17 randomized clinical trials based on nevirapine administration), demonstrated that nevirapine ranked fourth (with around $10 \%$ of treated patients who developed a serum transaminase rise greater than 5-fold, compared with normal levels), after abacavir and other compounds, with efavirenz ranking fifth (4). Finally, in their recent Cochrane revision of April 2006 (17), Siegfried et al. assessed nevirapinebased regimens as providing favorable efficacy and durability, associated with a contained adverse effect profile and potential for drug-drug interactions. In the published series quoted above $(1,17)$, around $40 \%$ of treated patients were represented by females, and no significant difference as to toxicity and efficacy was found compared with efavirenz-treated subjects (17).

\section{REFERENCES}

1. Bonjoch A, Paredes R, Domingo P, et al. Long-term safety and efficacy of nevirapine-based approaches in HIV type 1-infected patients. AIDS Res Hum Retroviruses 2006; 22: 321-329.

2. De Requeña DG, Jimenez-Nacher I, Soriano V. Changes in nevirapine plasma concentrations over time and its relationship with liver enzyme elevations. AIDS Res Hum Retroviruses 2005; 21: 555-559.

3. DHHS Panel on Antiretroviral Guidelines for Adults and Adolescents - A Working Group of the Office of AIDS Research Advisory Council (OARAC). Guidelines for the use of antiretroviral agents in HIV-1 infected adults and adolescents. Available on the world wide web, at http://AIDSinfo.nih.gov: 1-112.
4. Dieterich DT, Robinson PA, Love J, Sten JO. Druginduced liver injury associated with the use of nonnucleoside reverse transcriptase inhibitors. Clin Infect Dis 2004; 38 (Suppl. 2): S80-S89.

5. Hitti J, Frenkel LM, Stek AM, Nachman SA, et al. Maternal toxicity with continuous nevirapine in pregnancy: results from PACTG 1022. J Acquir Immune Defic Syndr 2004; 36: 772-776.

6. Joao EC, Calvet GA, Menezes JA, et al. Nevirapine toxicity in a cohort of HIV-1-infected pregnant women. Am J Obstet Gynecol 2006; 194: 199-202.

7. Joy S, Poi M, Hughes L, et al. Third-trimester maternal toxicity woth nevirapine use in pregnancy. Obstet Gynecol 2005; 106 (5 Pt 1): 1032-1038.

8. Kappelhoff BS, Van Leth F, Robinson PA, et al. Are adverse events of nevirapine and efavirenz related to plasma concentrations? Antivir Ther 2005; 10: 489-498.

9. Manfredi R. HIV infection, antiretroviral therapy, and hepatic function. Emerging epidemiological, pathogenetic, and clinical issues, and their consequences on disease management. AIDS 2003; 17: 2253-2256.

10. Manfredi R, Calza L, Chiodo F. Efavirenz versus nevirapine in current clinical practice: a prospective, openlabel observational study. J Acquir Immune Defic Syndr 2004; 35: 492-502.

11. Manfredi R, Calza L, Chiodo F. A case-control study of HIV-associated pancreatic abnormalities during HAART era. Focus on emerging risk factors and specific management. Eur J Med Res 2004; 9: 537-544.

12. Manfredi R, Calza L, Chiodo F. Prospective, open-label comparative study of liver toxicity in an unselected population of HIV-infected patients treated with efavirenz or nevirapine. HIV Clin Trials 2005; 6: 302-311.

13. Milinkovic A, Martínez E. Nevirapine in the treatment of HIV. Expert Rev Anti Infect Ther 2004; 2: 367-373.

14. No author listed. FDA advisory on nevirapine. AIDS Treat News 2005; Jan 28; (409): 7

15. Ribera E, Rodriguez-Pardo D, Rubio M, et al. Efficacy and safety of once-daily combination therapy with didanosine, lamivudine and nevirapine in antiretroviral-naïve HIV-infected patients. Antivir Ther 2005; 10 : 605-614.

16. Sabbatani S, Manfredi R, Biagetti C, Chiodo F. Antiretroviral therapy in the real world. Populationbased pharmacoeconomic analysis of administration of anti-HIV regimens to 990 patients. Clin Drug Invest 2005; 25: 527-535.

17. Siegfried NL, Van Deventer PJ, Mahomed FA, Rutherford GW. Stavudine, lamivudine and nevirapine combination therapy for treatment of HIV infection and AIDS in adults. Cochrane Database Syst Rev 2006; 2 : CD004535.

18. Taiwo BO. Nevirapine toxicity. Int J STD AIDS 2006; 17: 364-369.

19. Van Leth F, Phanuphak P, Ruxrungtham K, et al. Comparison of first-line antiretroviral treatment with regimens including nevirapine, efavirenz, or both drugs, plus stavudine and lamivudine: a randomised open-label trial, the $2 \mathrm{NN}$ study. Lancet 2004; 363:1253-1263.

\section{Roberto Manfredi}

Malattie Infettive

Policlinico S. Orsola-Malpighi

Via Massarenti 11 - 40138 Bologna

Tel.: 0516363355 - Fax: 051343500

E-mail: roberto.manfredi@unibo.it 